Rev. Int. Contam. Ambie. 37, 211-226, 2021

https://doi.org/10.20937/RICA.53830

\title{
HEALTH RISK DUE TO HEAVY METAL(LOID)S EXPOSURE THROUGH FINE PARTICULATE MATTER AND SEDIMENTED DUST IN PEOPLE LIVING NEXT TO A BEACH CONTAMINATED BY MINE TAILINGS
}

\author{
Riesgo en salud por exposición a metal(oid)es pesados a través de material particulado fino y polvo sedimentado \\ en personas que viven adyacentes a una playa contaminada por relaves mineros
}

\author{
Dante D. CÁCERES ${ }^{1,2 *}$, Paulina FLORES JIMÉNEZ ${ }^{3}$, Kelly HERNÁNDEZ ${ }^{3}$, \\ Frederico PERES ${ }^{4}$, Ana K. MALDONADO ${ }^{1}$, José KLARIÁN ${ }^{5}$ y Dante A. CÁCERES ${ }^{6}$
}

${ }^{1}$ Programa de Salud Ambiental, Escuela de Salud Pública, Facultad de Medicina, Universidad de Chile, Santiago, Chile.

${ }^{2}$ Facultad de Ciencias de la Salud, Universidad de Tarapacá, Arica, Chile.

${ }^{3}$ International Exchange Program for Minority Student, Department of Preventive Medicine, Icahn School of Medicine, Mount Sinai, New York, NY, USA.

${ }^{4}$ Centro de Estudios de Salud del Trabajador y Ecología Humana, Escuela Nacional de Salud Pública Sergio Arouca, Fundación Oswaldo Cruz, Río de Janeiro, Brasil.

${ }^{5}$ Departamento de Prevención de Riesgos y Medio Ambiente, Universidad Tecnológica Metropolitana, Santiago, Chile.

${ }^{6}$ Facultad de Medicina Veterinaria, Universidad Austral de Chile, Valdivia, Chile.

*Author for correspondence: dcaceres@med.uchile.cl

Key words: human risk, heavy metal, metalloids, tailings, $\mathrm{PM}_{2.5}$, sedimented dust.

\begin{abstract}
The non-carcinogenic hazard index (HI) and the carcinogenic risk index (CRI) due to exposure to metal(loid)s were assessed in children and adults living adjacent to a beach contaminated with mine tailings. Chromium $(\mathrm{Cr})$, nickel $(\mathrm{Ni})$, cadmium $(\mathrm{Cd})$, arsenic $(\mathrm{As})$, zinc $(\mathrm{Zn})$, copper $(\mathrm{Cu})$, lead $(\mathrm{Pb})$ and manganese $(\mathrm{Mn})$ were determined in fine particulate matter $\left(\mathrm{PM}_{2.5}\right)$ and sedimented dust $(\mathrm{SD})$ in school and residential microenvironments. The $\mathrm{HI}$ in children was 13.8, 8.1, 5.4, 2.4, 2.3 and 1.8-times greater than the safety threshold (1.0) for $\mathrm{Cr}, \mathrm{As}, \mathrm{Pb}, \mathrm{Mn}, \mathrm{Cu}$, and $\mathrm{Cd}$, respectively; $84.1 \%$ explained by dermal contact and $10.9 \%$ by ingestion of SD. The CRI for $\mathrm{Cr}$ and As was 3.7 and 3.2 times above the acceptable risk $\left(>1 \times 10^{-4}\right)$, explained by the inhalation of $\mathrm{PM}_{2.5}$ and $\mathrm{SD}$, respectively. In adults, the CRI for As and $\mathrm{Cr}$ was 46.0 and 2.8 times greater than $1 \times 10^{-4}$; As risk is explained by dermal contact and inhalation of $\mathrm{SD}$, and $\mathrm{Cr}$ by inhalation of $\mathrm{PM}_{2.5}$. This study reports a high risk of potential adverse health effects on children and adults due to exposure to these elements present in the particles and dust studied.
\end{abstract}

Palabras clave: riesgo en salud humana, metales pesados, metaloides, relaves mineros, $\mathrm{PM}_{2.5}$, polvo sedimentado.

\section{RESUMEN}

Se evaluó el índice de peligro no carcinogénico (HI, por sus siglas en inglés) y el riesgo carcinogénico (CRI, por sus siglas en inglés) por exposición a metal(oide)s en niños $\mathrm{y}$ adultos que viven adyacentes a una playa masivamente contaminada con relaves 
mineros. Se determinó la presencia de Cromo $(\mathrm{Cr})$, níquel $(\mathrm{Ni})$, cadmio $(\mathrm{Cd})$, arsénico (As), zinc $(\mathrm{Zn})$, cobre $(\mathrm{Cu})$, plomo $(\mathrm{Pb})$ y manganeso $(\mathrm{Mn})$ en partículas finas $\left(\mathrm{PM}_{2.5}\right)$ y en polvo sedimentado (PS), recolectados en microambientes residenciales y escolares, respectivamente. El $\mathrm{HI}$ en niños fue 13.8, 8.1, 5.4, 2.4, 2.3 y 1.8 veces mayor que el umbral de seguridad (1.0) para $\mathrm{Cr}, \mathrm{As}, \mathrm{Pb}, \mathrm{Mn}, \mathrm{Cu}$ y $\mathrm{Cd}$, respectivamente, lo cual se explica mayormente por la exposición a PS a través de la vía dérmica $(84.1 \%)$ y la digestiva $(10.9 \%)$. El CRI para Cr y As fue 3.7 y 3.2 veces superior al umbral tolerable $\left(>1 \times 10^{-4}\right)$, lo cual se explica por la inhalación de $\mathrm{PM}_{2.5}$ y PS, respectivamente. En adultos, el HI fue inferior a 1, mientras que el CRI para As y Cr fue 46.0 y 2.8 veces mayor que el umbral $1 \times 10^{-4}$. El ingreso del As al organismo ocurre por contacto dérmico y por ingestión de PS, mientras que el de Cr ocurre por inhalación de $\mathrm{PM}_{2.5}$. En este estudio informamos un elevado riesgo potencial de presentar efectos adversos en la salud de niños y adultos por la exposición a los elementos presentes en partículas y polvo sedimentado.

\section{INTRODUCTION}

Chile is recognized worldwide because much of its economy is based on the mining activity, especially the exploitation of copper deposits, which are concentrated in the north of the country. This has not only meant economic benefits, but also has had serious environmental effects due to air pollution, and contamination of water, soils and marine areas (Carkovic et al. 2016, Tapia et al. 2018). The city of Chañaral is located in the coast of the Atacama region. Until the 1970s, its bay was one of the most biodiverse coastal areas of Chile thanks to the positive influence of the Humboldt current (Vergara 2011). Nowadays, this bay is massively contaminated and embanked with mine tailings which were products of the copper mining activity of the last century, especially the Andean mining centers El Salvador and Potrerillos (Vergara 2011). For 50 years these mining centers poured their tailings into the El Salado river that flows into the bay, leading to the formation of an artificial beach about $10 \mathrm{~km}$ long by $1 \mathrm{~km}$ wide with an estimated depth between 10 and $15 \mathrm{~m}$ (Mesías et al. 2018). These mineral wastes have produced a marked deleterious effect on marine flora and fauna due to their chemical metal composition, many components of which have known toxic effects for the environment (Castilla 1983, Lee and Correa 2005, Medina et al. 2005). The hydrological system of the coastal zone is dominated by high and low tides that react with tailings deposits when they are wet at high tide, favoring the movement of metals towards the surface, which in turn facilitates their diffusion to the environment (Dold 2006).

The city of Chañaral is located adjacent to the bay (Fig. 1); its population is constantly exposed to dust and particulate material that rises by wind action, especially in the spring and summer months

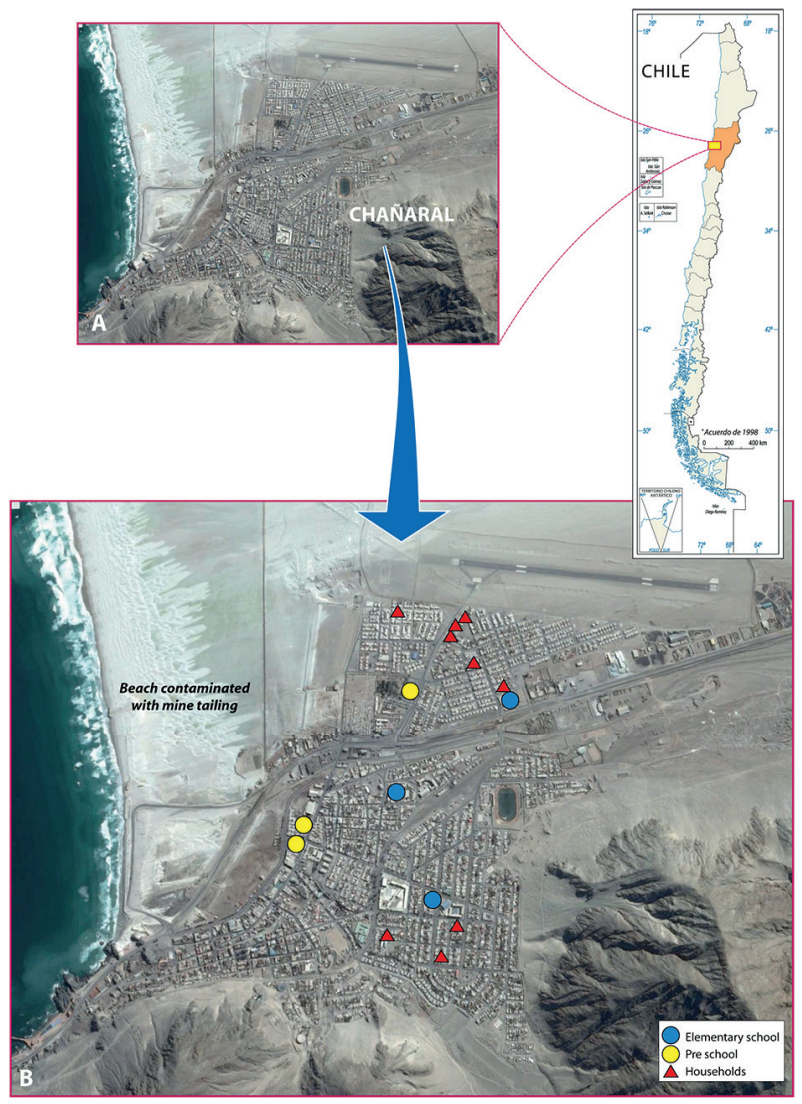

Fig. 1. (a) Extension of the beach with residues of the mining activity (tailings). (b) Location of the city of Chañaral. Source: Google Earth.

(Yohannessen et al. 2015). According to Astudillo (2008), "seasonal winds, mainly during spring and early summer, raise impressive amounts of particulate matter from the beach, creating an irrespirable environment for people"). Studies on this material have determined high content of copper $(\mathrm{Cu})$, zinc 
( $\mathrm{Zn})$, molybdenum (Mo), nickel (Ni), mercury (Hg), lead $(\mathrm{Pb})$, manganese (Mn) and arsenic (As) (Ramírez et al. 2005), many of which have serious effects on health (Barceloux 1999, Ratnaike 2003, Bernard 2008, Das et al. 2008, Morais et al. 2012, Roohani et al. 2013, Kim et al. 2015, O'Neal and Zheng 2015, Stern 2010, Wani et al. 2015) (Table I).

Transition metals such as iron $(\mathrm{Fe}), \mathrm{Cu}$, vanadium (V), $\mathrm{Hg}$, and $\mathrm{Zn}$ are known to produce severe toxicity in exposed tissues, which will depend on the type of element and its physicochemical characteristics as well as the metabolic pathways of the organisms (Morais et al. 2012). Systemic gastrointestinal, neurological (central and peripheral), hematopoietic, renal, respiratory and cardiovascular effects have been reported (Gray et al. 2015). Many metals/metalloids (hereafter metal[loid]s) such as inorganic As, hexavalent chromium (CrVI), cadmium (Cd) and nickel $(\mathrm{Ni})$ have recognized carcinogenic effects (Morais et al. 2012, Chen et al. 2019). The pollutants associated with mining activity are mostly heavy metal(loid)s, which generate a strong impact on the entire ecosystem (water, air, soil, biota) that can be irreparable. These reach the ground through the disposal of mining waste such as tailings, and the air by means of emission and resuspension of particulate material and dust, remaining and infiltrating the environmental substrates at local, regional and global levels (Csavina et al. 2012, Voulvoulis et al. 2013). Several studies have shown that living near mining waste is a risk factor for the health of populations due to the exposure to heavy to metal such as $\mathrm{Pb}, \mathrm{Cd}, \mathrm{Mn}$, and As (Fonturbel et al. 2011, Csavina et al. 2012, Barbieri et al. 2014).
Exposure to pollutants within school grounds is a relevant research area in terms of children's environmental health, mainly because children are highly susceptible to the impact of air pollutants and that they remain from 6 to $10 \mathrm{~h}$ inside indoor spaces (Oeder et al. 2012). Indoor school microenvironments have been described as one of the most contaminated places, reporting high levels of particles, gases and microorganisms (bacteria, fungi), many of which are associated with serious acute and/or chronic health effects (Cartieaux et al. 2011).

The objective of the present study was to estimate the potential risks of adverse effects on the health of the Chañaral population living near a beach massively contaminated with mining tailings, by exposure to heavy metal(loid)s determined in fine particulate material $\left(\mathrm{PM}_{2.5}\right)$ and in sedimented dust (SD) in school and residential microenvironments.

\section{MATERIALS AND METHODS}

\section{Study location}

The study was conducted in the urban area of the city of Chañaral, located in the Atacama Region in northern Chile (Fig. 1 A), which is geographically characterized by arid desert conditions with very low rainfall and low vegetation on the coastal edge that benefits from the humidity of the ocean. It is located on a narrow marine terrace approximately $20 \mathrm{~m}$ above the average sea level; it has coastal rock outcrops that rise above $200 \mathrm{~m}$, with an extensive beach that faces

TABLE I. ADVERSE EFFECTS ON HEALTH DUE TO EXPOSURE TO HEAVY METAL(LOID)S.

\begin{tabular}{|c|c|c|c|c|c|c|c|c|c|c|c|c|}
\hline \multirow{2}{*}{ Adverse effects } & \multicolumn{8}{|c|}{ Non-carcinogenic } & \multicolumn{4}{|c|}{ Carcinogenic } \\
\hline & As & $\mathrm{Cd}$ & $\mathrm{Cr}(\mathrm{VI})$ & $\mathrm{Cu}$ & $\mathrm{Ni}$ & $\mathrm{Mn}$ & $\mathrm{Pb}$ & $\mathrm{Zn}$ & As & $\mathrm{Cd}$ & $\mathrm{Cr}(\mathrm{VI})$ & $\mathrm{Ni}$ \\
\hline Cardiovascular & $x$ & $x$ & & & & & & & & & & \\
\hline Dermal & $x$ & & $x$ & & $x$ & & & & $x$ & & & \\
\hline Endocrine & $x$ & & & & & & & & & & & \\
\hline Skeletal & & $x$ & & & & & & & & & & \\
\hline Gastrointestinal & $x$ & & & $x$ & & $x$ & $x$ & $x$ & & & & \\
\hline Hematological & $x$ & & & & & & $x$ & $x$ & $x$ & & & \\
\hline Hepatic & $x$ & & & & & & & & $x$ & & & \\
\hline Immunologic & & & & & & & & & & & & \\
\hline Neurologic & $x$ & & & $x$ & $x$ & $x$ & $x$ & & & & & \\
\hline Renal & $x$ & $x$ & $x$ & & $x$ & & & & $x$ & $x$ & & \\
\hline Reproductive & $x$ & & & & $x$ & $x$ & $x$ & & $x$ & & & \\
\hline Respiratory & $x$ & $x$ & & $x$ & & & & $x$ & $x$ & $x$ & $x$ & $x$ \\
\hline
\end{tabular}

Sources: As: Ratnaike 2003, Cd: Bernard 2008, Cr(VI): Barceloux 1999, Cu: Stern 2010, Ni: Das et al. 2008, Mn: O’Neal and Zheng 2015, Pb: Wani et al. 2015, Zn: Roohani et al. 2013. 
northeast. According to the 2012 census (BCN 2015), it has 13781 inhabitants, a high percentage of whom are concentrated in the urban area.

\section{Sampling of $\mathbf{P M}_{2.5}$ and SD}

A total of $60 \mathrm{PM}_{2.5}$ samples and $32 \mathrm{SD}$ samples were collected in six schools (three elementary and three basic schools) and 10 houses, during winter (July $1-8,2012$ ) and summer (December 12-18, 2013), respectively. The houses and schools studied correspond to the residence and school establishments of the children who participated in the study by Yohannessen et al. (2015) (Fig. 1b). Schools were sampled during the school day (8:30 to $16: 30$ LT) in classrooms, courtyards and administrative offices. Sampling of houses was carried out in the living room and the back yard for a period of $24 \mathrm{~h}$. $\mathrm{PM}_{2.5}$ were collected on Teflon filters of $37 \mathrm{~mm}$ using 44XR Universal Personal Sample Pump (SKC Inc, Eighty Four, Pennsylvania, USA), at a flow of $4 \mathrm{~L} / \mathrm{min}$, using an inertial particulate impactor $\mathrm{PEM}^{\mathrm{TM}}$ (Personal Environmental Monitor) of $2.5 \mu \mathrm{m}$ diameter (Anderson and Albert 2019). The concentration of $\mathrm{PM}_{2.5}$ was determined by gravimetry by calculating the difference in weight of the filters before and after sampling. The $\mathrm{PM}_{2.5}$ samplers were installed $1 \mathrm{~m}$ high and $50 \mathrm{~cm}$ from the walls, away from the windows in indoor and outdoor microenvironments (Mesías et al. 2018). On the other hand, the SD samples were collected with a High-Volume Small Surface Sampler (HVS3) developed by Environmetrics and Engineering Plus for the EPA. The time and surface to be sampled varied depending on the degree of cleanliness of the microenvironment studied and according to the specifications of the sampler manufacturer, considering the standard methodology for collecting dust samples (ASTM 2003). SD samples were stored in polyethylene bottles for later analysis.

\section{Laboratory analysis}

The elements determined were $\mathrm{Cr}, \mathrm{Ni}, \mathrm{Cd}, \mathrm{As}$, $\mathrm{Zn}, \mathrm{Cu}, \mathrm{Pb}$, and $\mathrm{Mn}$. The treatment of filters and determinations of metal(loid)s in $\mathrm{PM}_{2.5}$ were performed in the ChesterLab, Tigard, OR, USA (www. chesterlab.net) laboratory by X-ray fluorescence (XRF Analyte), using a Kevex Model 770 spectrometer according to the IO-3.3 protocol established by the U.S. Environmental Protection Agency (USEPA 1999). The metal(loid)s in SD were quantified by mass spectrometry (MS) with source of inductive coupling plasma (ICP) in the laboratory of the Department of Environmental Sciences, Life Sciences Division, University of Guanajuato, Mexico. In both cases, standards certified by the National Institute for
Standards and Tests of the United States of America (NIST) were used for quality control. For $\mathrm{PM}_{2.5}$, multielement standards (QS285) and NIST reference material (SRM 1832; 1833; 2783) were used (Mesías et al. 2018). Certified standards of metals SRM 2710 were used for the SD determinations.

\section{Risk assessment in humans}

The methodologies established by the USEPA for evaluation of non-carcinogenic and carcinogenic risks were used (USEPA 1989, 2009). The average daily dose intake (ADD) of each metal(loid)s to the organism was calculated for ingestion (ing), dermic absorption (der), and inhalation (inh) of SD, using equations 1, 2 and 3. In the case of $\mathrm{PM}_{2.5}$, the intake through inhalation, exposure concentration (EC) was calculated using equation 4.

$$
\begin{aligned}
& A D D_{\text {ing }}(m g / k g-d a y)=\frac{C I R E F E D C F}{B W A T} \\
& A D D_{\text {der }}(m g / k g-d a y)=\frac{C S A A F A B S d E F E D C F}{B W A T} \\
& A D D_{\text {inh_sd }}\left(m g / m^{3}-d a y\right)=\frac{C \operatorname{InhREFED}}{P E F B W \mathrm{AT}} \\
& E C_{\text {inh_PM25 }}\left(\mu g / m^{3}-d a y\right)=\frac{C E T E F E D}{A T}
\end{aligned}
$$

where $C$ is the concentration of metal(loid)s in SD $\left(\mathrm{mg} / \mathrm{kg}\right.$ ) or air $\left(\mu \mathrm{g} / \mathrm{m}^{3}\right), E D$ the exposure duration (in years), $E F$ the exposure frequency (days/years), $E T$ the exposure time (hours/day), IRing the ingestion rate (mg/days), $B W$ the body weight $(\mathrm{Kg}), A T$ the exposure averaging time (days), $C F$ the conversion factor $(\mathrm{kg} /$ $\mathrm{mg}), A F$ the solid material to skin adherence factor to dust $\left(\mathrm{mg} / \mathrm{cm}^{2} / \mathrm{d}\right), S A$ the skin surface area available for contact $\mathrm{cm}^{2}, P E F$ the particle emission factor $\left(\mathrm{m}^{3} /\right.$ $\mathrm{kg}$ ), and IRinh the inhalation rate $\left(\mathrm{m}^{3} / \mathrm{d}\right)$ (Table II). To estimate the exposure of the metal(loid)s through $\mathrm{PM}_{2.5}$ and $\mathrm{SD}$ in children and adults, $16 \mathrm{~h}$ a day were considered. For children we integrated $8 \mathrm{~h}$ at school and $8 \mathrm{~h}$ at home. In both cases, no difference was made between weekdays and weekends because schools and houses are in the radius of the contaminated area (Mesías et al. 2018). On the other hand, to calculate the risk in children and adults, we used the anthropometric parameters that have been reported for the Chilean population (Castellucci et al. 2015, MINSAL 2018).

To estimate ADD by different routes through $\mathrm{PM}_{2.5}$ and $\mathrm{SD}$, the upper limit of the $95 \%$ confidence interval of the concentration for the elements was determined using the ProUCL V5.1 software for EPA 
TABLE II. PARAMETERS USED TO CALCULATE AVERAGE DAILY DOSE, EXPOSURE CONCENTRATION, REFERENCE DOSE VALUES, CANCER SLOPE AND ABSORPTION FACTORS FOR HEAVY METAL(LOID)S.

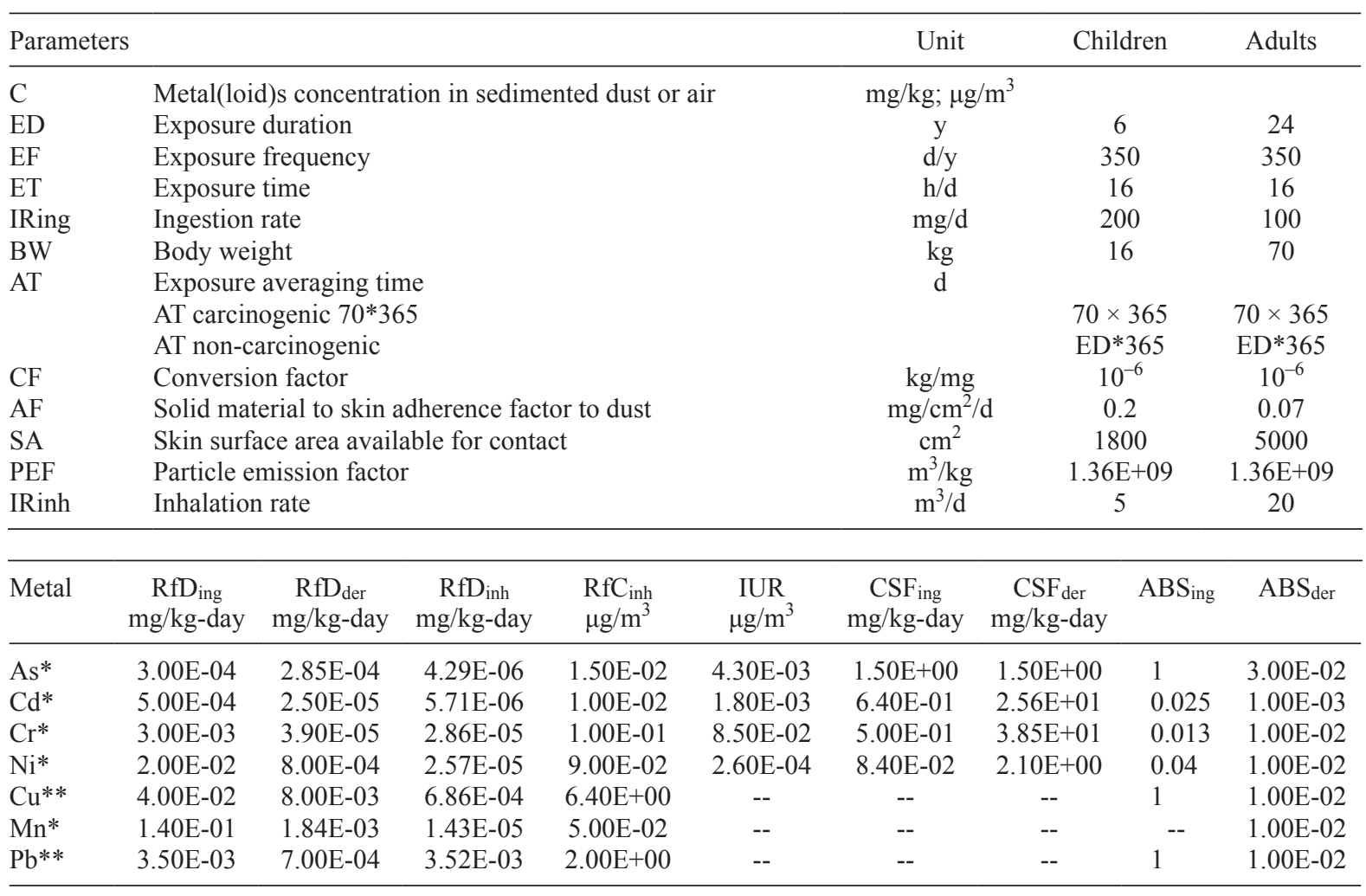

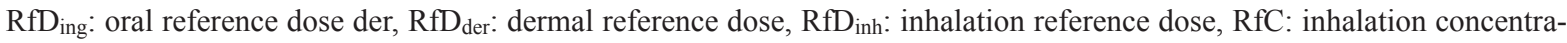
tion reference dose, IUR: inhalation unit risk, $\mathrm{CSF}_{\text {ing: }}$ oral cancer slope factor, $\mathrm{CSF}_{\text {der: }}$ dermal cancer slope factor, $\mathrm{ABSing}$ : gastrointestinal absorption factor, ABSder: dermal absorption factor

*Asante-Duah 2017, **Masto et al. 2017

environmental data analysis (https://www.epa.gov/ land-research/proucl-software).

\section{Non-carcinogenic risk (HQ)}

The non-carcinogenic risk (HQ: hazard quotient) was calculated as the ratio of the estimated metal exposure to the route-specific dose (ADD) using equation 5 .

$$
\begin{array}{r}
H Q=\frac{A D D_{i n h}}{(R f C) \times 1000 \mu g / m g}= \\
\frac{A D D_{i n g}}{R f D_{\text {ing }}}=\frac{A D D_{\text {der }}}{R f D_{\text {ing }} x A B S_{\text {ing }}}
\end{array}
$$

where $R f C\left(\mathrm{mg} / \mathrm{m}^{3}\right.$-day) is the reference dose by inhalation and $R f D_{\text {ing }}(\mathrm{mg} / \mathrm{kg}$-day) the reference dose per ingestion. When the pollutants are diverse, the total risk hazard index (HI) can be estimated using equation 6, which is the sum of the individual HQs.

$$
H I=\sum_{i=1}^{n} H Q_{i}
$$

\section{Carcinogenic risk (CR)}

The carcinogenic risk (CR) was calculated by multiplying the ADD route-specific per cancer slope factor (CSF) or the inhalation unit risk (IUR) of cancer using $\mathrm{Eq}(7)$.

$$
\begin{aligned}
& R C=I U R \times A D D_{i n h}=C S F_{i n g} \times A D D_{\text {ing }}= \\
&\left(\frac{C S F_{i n g}}{A B S_{i n g}}\right) \times A D D_{\text {der }}
\end{aligned}
$$

where: IUR $\left(\mu \mathrm{g} / \mathrm{m}^{3}\right)$ is the inhalation risk unit, $A D D$ inh; ing; der the concentration of exposure by different pathways, $C S F_{\text {ing }}$ the cancer slope factor ingestion $1 /\left(\mathrm{mg} / \mathrm{kg}\right.$-day), and $A B S_{\text {ing }}$ the gastrointestinal absorption factor. When the pollutants are diverse the carcinogenic risk index CRI can be calculated using 
equation 8 , which is the sum of the CR of each element evaluated.

$R C I=\sum_{i=1}^{n} C R_{i}$

\section{Interpretation of HQ, HI, CR and CRI}

If the calculated values of HQ and HI are > 1, it indicates a greater likelihood of adverse noncarcinogenic health impacts of pollutants, otherwise adverse effects are unlikely. Because carcinogenic agents do not have an effect threshold, that is, there is no safe level of exposure, the EPA has established acceptable values for the protection of human health between $10^{-4}$ and $10^{-6}$, that is, exposure for life does not produce more than one case per 10000 or one per 1000000 of cancer in the population (Asante-Duah 2017). Above these values, an excess cancer risk over expected cases is considered. Table II presents the parameters to estimate ADD, EC and factors used to calculate the non-carcinogenic (HQ; HI) and carcinogenic (CR; CRI) risks of the present study.

\section{Data analysis}

The results are presented as descriptive statistics of position and dispersion. The risk calculations were performed in Microsoft Excel software for each item. Statistical analyses were performed with the Stata v. 12 software.

\section{RESULTS AND DISCUSSION}

\section{Concentration levels of adsorbed metal(loid)s in SD and $\mathbf{P M}_{2.5}$}

Table III describes the concentrations of metal(loid)s determined in SD and $\mathrm{PM}_{2.5}$ for homes and schools. Descriptive statistics are presented integrating the concentrations of indoor and outdoor microenvironments for homes and schools, respectively, since no statistically significant differences were observed (supplementary data). The order of the average concentrations of metal(loid)s in $\mathrm{SD}$ was $\mathrm{Cu}$ $>\mathrm{Zn}>\mathrm{Mn}>\mathrm{Pb}>\mathrm{As}>\mathrm{Ni}>\mathrm{Cr}>\mathrm{Cd}>$, and $\mathrm{Cu}>\mathrm{Zn}$ $>\mathrm{Mn}>\mathrm{Pb}>\mathrm{As}>\mathrm{Cr}>\mathrm{Ni}>\mathrm{Cd}$ in houses and schools, respectively. For $\mathrm{PM}_{2.5}$ they were $\mathrm{Cu}>\mathrm{Cr}>\mathrm{Zn}>\mathrm{Pb}$ $>\mathrm{Mn}>\mathrm{As}>\mathrm{Cd}>\mathrm{Ni}$, and $\mathrm{Cr}>\mathrm{Cu}>\mathrm{Zn}>\mathrm{Pb}>\mathrm{Mn}$ $>\mathrm{As}>\mathrm{Cd}>\mathrm{Ni}$ in homes and schools, respectively. The coefficients of variation for the metal(loid)s determined in $\mathrm{PM}_{2.5}$ and in SD were high (Table III), indicating the great variability of concentrations determined in the different environments, which is why the upper limit of the $95 \%$ confidence interval was used (UCL $95 \%$ ) to estimate ADD by different routes (USEPA 2015).

Various studies have determined high average levels of $\mathrm{Cu}(3500 \mathrm{mg} / \mathrm{kg}), \mathrm{Zn}(52 \mathrm{mg} / \mathrm{kg})$ and $\mathrm{Ni}$ $(102 \mathrm{mg} / \mathrm{kg})$ in Chañaral Bay compared with Playa Pan de Azúcar located $15 \mathrm{~km}$ to the north $(\mathrm{Cu}, 34 \mathrm{mg} /$ $\mathrm{kg} ; \mathrm{Zn}, 26 \mathrm{mg} / \mathrm{kg}$, and Ni, $54 \mathrm{mg} / \mathrm{kg}$ ), which would be associated with tailing deposits resuspended by prevailing winds towards the urban area (Castilla 1983, Wisskirchen and Dold 2006, Vergara 2011). There are not regulations in Chile for soil metal contents (Mesías et al. 2018).

Montenegro et al. (2009) studied heavy metals contents in soils near a copper tailing in the Coquimbo region (north central), determining high concentrations for $\mathrm{Cu}, \mathrm{Mn}, \mathrm{Zn}, \mathrm{Cr}, \mathrm{Cd}$ and $\mathrm{Pb}$ in sectors adjacent to tailings sites, suggesting that winds would be dispersing these metal(loid)s, which would explain their greater presence.

Gidhagen et al. (2002) studied the sources of As in $\mathrm{MP}_{10}$ in central-northern Chile, demonstrating a large regional impact of anthropogenic emissions from copper smelters, which would be more relevant than the resuspension of SD, and would explain the high levels found in soils of the Atacama region. Ramírez et al. (2005) analyzed the sands of the Chañaral coast beach $(<63 \mu \mathrm{m}$ in diameter), reporting high concentrations for $\mathrm{Mn}>\mathrm{Cu}>\mathrm{Zn}>\mathrm{Pb}>\mathrm{N}$ i $>$ $\mathrm{Cd}$ which would be associated to the influence of the El Salvador mine, similar to the pattern reported for $\mathrm{SD}$ in the present study.

Jorquera and Barraza (2013) determined the sources of metal(loid)s in $\mathrm{PM}_{2.5}$ in desert areas of northern Chile using statistical dispersion models, reporting the following pattern of distribution and concentration of heavy metal(loid)s: $\mathrm{Cu}>\mathrm{Zn}>\mathrm{As}$ $>\mathrm{Pb}>$ and $\mathrm{Ni}$, similar to those reported in our study. According to the authors, the most likely source for $\mathrm{Ni}, \mathrm{Zn}$, and $\mathrm{Pb}$ would be elements present in fugitive $\mathrm{PM}_{2.5}$ that would come from mineral deposits, as could be the case of tailings deposits present in the Chañaral Bay.

In 2016, Carkovic et al. (2016) reported in a study carried out in the city of Copiapó high concentrations of $\mathrm{Mn}>\mathrm{Cu}>\mathrm{Zn}>\mathrm{Pb}>\mathrm{As}$ in soil, sedimented dust and tailings samples, whose concentrations were higher in places near former tailings deposits associated with copper mining. The authors suggest that the high concentrations of $\mathrm{Cu}$ and $\mathrm{Zn}$ would be associated with the mining tailings present in this city and old $\mathrm{Cu}$ refineries. Also, these authors indicate that the concentrations of these metal(loid)s determined in 


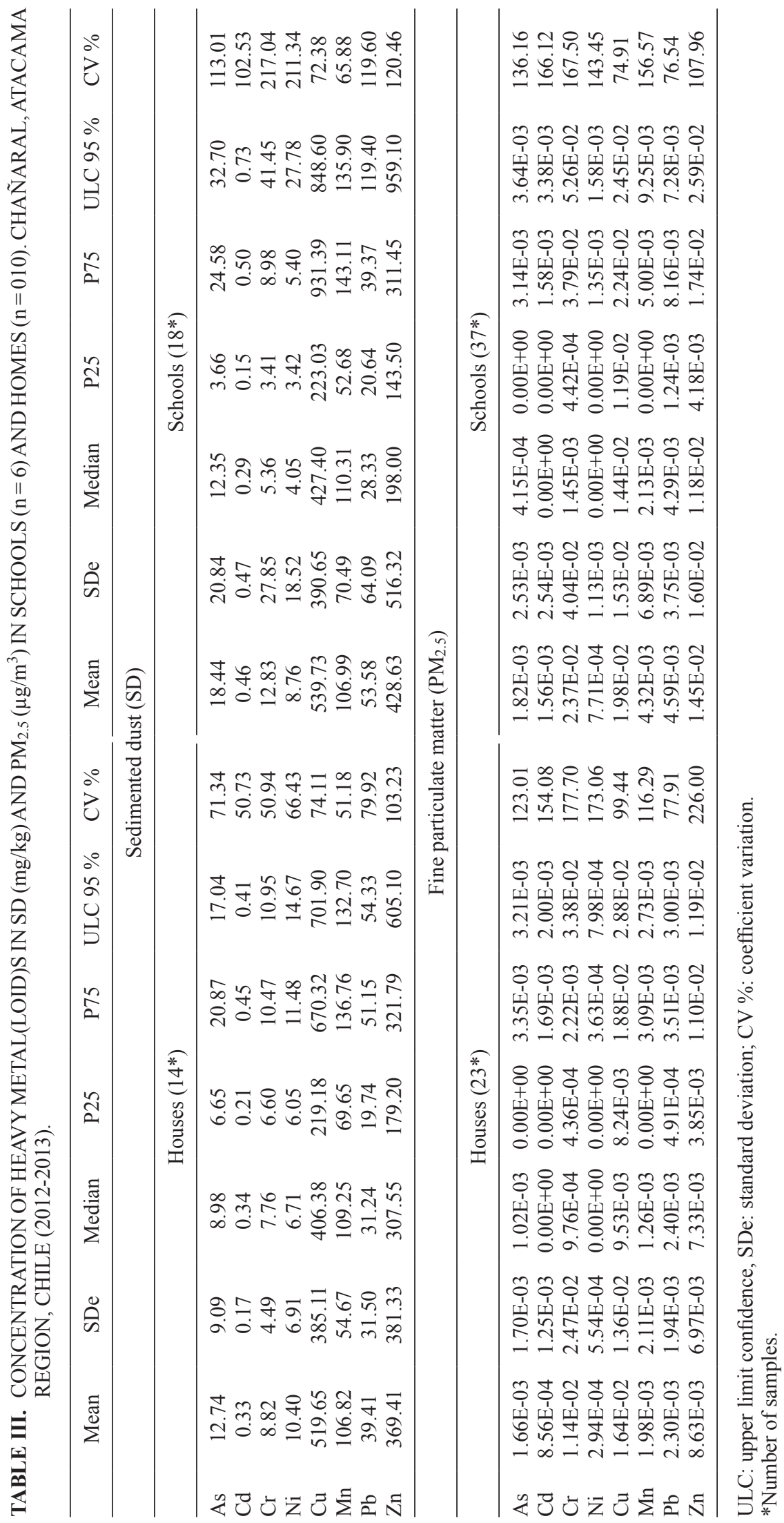


dust samples are greater as the particle size is smaller, since they offer a greater surface area for adsorption in relation to their volume. Several authors agree that particle size and chemical composition are relevant factors that determine the danger of these particles (Schwartz and Neas 2000, Diociaiuti et al. 2001). These results reinforce the findings of our study, where $\mathrm{Cu}, \mathrm{Zn}$ and $\mathrm{Pb}$ appear as the most abundant species, which points directly to tailings deposits in Chañaral Bay.

Few studies in Latin America have determined heavy metals in sedimented dust or particulate material associated with mining activities or mining waste. In Bolivia, a country with a mining tradition, studies of exposure to metals have been carried out in populations that are adjacent to mining operations. In mining districts of Oruro, the concentration of metal(loid)s in household SD and the hair of children aged 7 to 12 years was evaluated, finding significant correlations for $\mathrm{As}, \mathrm{Cd}, \mathrm{Pb}, \mathrm{Sb}$ and $\mathrm{Sn}$, suggesting that in contexts of high pollution such as the city of Chañaral, SD in indoor spaces could be an important route of exposure for children, associated with their playful and restless behavior (Fonturbel et al. 2011, Barbieri et al. 2014). Goix et al. (2011) described that the polymetallic pattern $(\mathrm{As}, \mathrm{Cd}, \mathrm{Cu}, \mathrm{Sb}, \mathrm{Pb}$ and $\mathrm{Zn}$ ) determined in the same study area could be related to smelting emissions, especially in the $\mathrm{PM}_{2.5}$ fraction, which are the smallest and most bioavailable particles for the population. This could also be reflecting the resuspension during the transport of ore from the mine to the smelter. Moreno et al. (2010) in Mexico reported high levels of $\mathrm{Ni}, \mathrm{Mn}, \mathrm{Cr}, \mathrm{Co}$, $\mathrm{Cd}, \mathrm{As}, \mathrm{Hg}$ in urine, and $\mathrm{Pb}$ in blood, respectively, over the reference values that have been determined in other countries, in children residing in the vicinity of the mining areas of the city of Taxco.

\section{Non-carcinogenic risk (HQ) through $\mathrm{PM}_{2.5}$ and SD}

As shown in Figure 2 (see Table SI in the supplementary material), the HI index for exposure to the metal(loid)s determined in $\mathrm{PM}_{2.5}$ was (in decreasing order) $\mathrm{Cr}>\mathrm{Mn}>\mathrm{Cd}>\mathrm{As}>\mathrm{Ni}>\mathrm{Pb}>\mathrm{Cu}>\mathrm{Zn}$ in children and $\mathrm{Cr}>\mathrm{As}>\mathrm{Cd}>\mathrm{Mn}>\mathrm{Zn}>\mathrm{Ni}>\mathrm{Cu}>\mathrm{Pb}$ in adults. This index was greater than 1 only for $\mathrm{Cr}$ in children, a value that is mainly explained through the inhalation route $(98.0 \%)$. This index was less than 1 in adults, indicating the absence of non-carcinogenic risks for these elements through fine PM. In contrast, the risk of a non-carcinogenic adverse effect from exposure to $\mathrm{As}, \mathrm{Pb}, \mathrm{Cu}, \mathrm{Cr}, \mathrm{Zn}, \mathrm{Mn}, \mathrm{Cd}$, and $\mathrm{Ni}$ through the ingestion of SD was 8.0, 5.4 and 2.3 times higher than the reference value, mainly explained by entry through the dermic $(88.5 \%)$ and digestive routes $(11.5 \%)$. The HI was less than 1 for all the elements studied in adults, either through
CHILDREN (PM25)

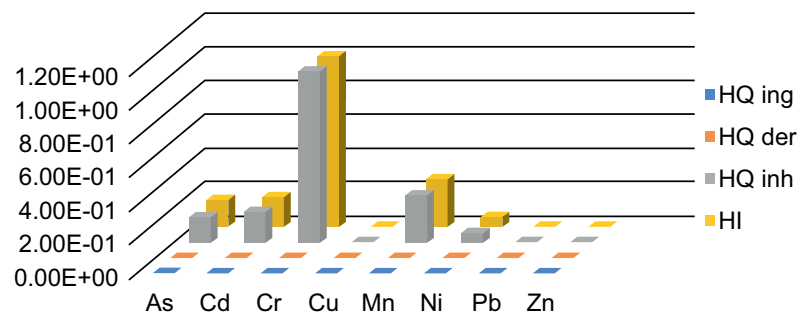

ADULTS (PM25)

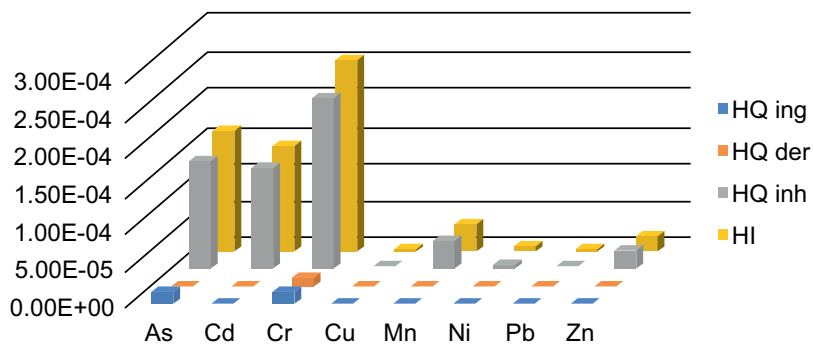

CHILDREN (SD)

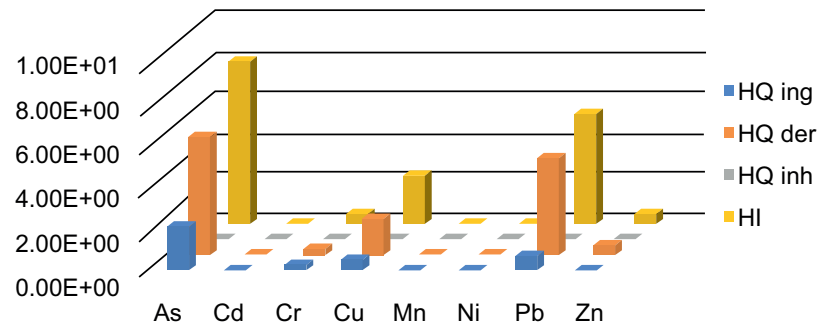

ADULTS (SD)

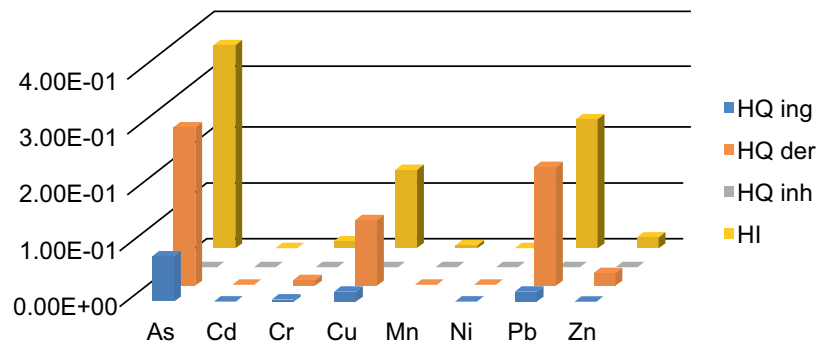

Fig. 2. Non-carcinogenic risk ratio (HQ: hazard quotient) and non-carcinogenic index (HI: hazard index) in children and adults due to exposure to metal(loid)s through $\mathrm{PM}_{2.5}$ and sedimented dust (SD). 
$\mathrm{PM}_{2.5}$ or SD. Considering the non-carcinogenic risk values integrating both exposures $\left(\mathrm{PM}_{2.5}+\mathrm{SD}\right)$, the $\mathrm{HI}$ was greater than 1 for $\mathrm{Cr}>\mathrm{As}>\mathrm{Pb}>\mathrm{Mn}>\mathrm{Cu}>$ $\mathrm{Cd}$ in children, which is explained by SD exposure; the dermal (84.1\%) and digestive routes $(10.9 \%)$ were the most significant. Figure 2 presents the HQ and $\mathrm{HI}$ in for the metals(oids) studied. The oral and dermal routes of exposure are the most relevant in children, which is clearly observed in the case of SD, since they have greater contact with soil and larger hand-mouth activity compared to adults (Csavina et al. 2012, Barbieri et al. 2014, Masto et al. 2017). In areas with mining influence, it has been determined that the oral and dermal routes are more relevant in terms of the risk of exposure to metal(loid)s compared to the inhalation route (Zhang et al. 2009, Zheng et al. 2010, 2013).

In a review of risk assessment due to exposure to heavy metals in mining soils in China, the authors concluded that the main route of exposure for $\mathrm{As}, \mathrm{Cd}$, $\mathrm{Cr}, \mathrm{Cu}$ and $\mathrm{Ni}$ would be dermic, and for $\mathrm{Pb}$ and $\mathrm{Zn}$ the digestive tract; people would be more exposed to $\mathrm{As}, \mathrm{Cd}, \mathrm{Ni}$ and $\mathrm{Pb}$ (Li et al. 2014). In a study conducted in Hezhang, China, Briki et al. (2017) compared the risk of exposure to metal(loid)s in the population living near mining areas, finding that the
HQ were greater than 1 for $\mathrm{Pb}>\mathrm{As}$, while $\mathrm{Cr}>\mathrm{Ni}$ $>\mathrm{Cd}>\mathrm{Zn}>\mathrm{Cu}$ were less than 1. Williamson et al. (2004) characterized particulate material from a $\mathrm{Cu}$ smelter in the mining city of Karabash in the Ural Mountains in Russia, experimentally determining that a high proportion of $\mathrm{Pb}, \mathrm{Zn}, \mathrm{Cd}$ and As would quickly be bioavailable, which would have implications in human health. Zhang et al. (2009) studied samples of $\mathrm{PM}_{10}$ collected on agricultural farms in a small mining town in southern China, finding high concentrations of $\mathrm{As}>\mathrm{Zn}>\mathrm{Pb}>\mathrm{Mn}>\mathrm{Cu}>\mathrm{Sb}>$ $\mathrm{Cd}$ and Mo. In Campo de Jales, a village around the abandoned Jales mine in Portuga,l which is highly contaminated with old mining tailings, high blood concentrations of $\mathrm{Pb}$ and $\mathrm{Cd}$ were determined, as well as a high prevalence of respiratory and irritative symptoms compared to a control locality (Mayan et al. 2006).

\section{Carcinogenic risk through $\mathbf{P M}_{2.5}$ and SD}

Figure 3 (see Table SII in the supplementary material) shows the estimation of the carcinogenic risk (CR) and the carcinogenic risk index (CRI) for $\mathrm{PM}_{2.5}$, SD and the integrated value, in decreasing order for the metal(loid)s studied. In children the $\mathrm{CR}$ by $\mathrm{PM}_{2.5}$ in decreasing order were $\mathrm{Cr}>\mathrm{As}>$
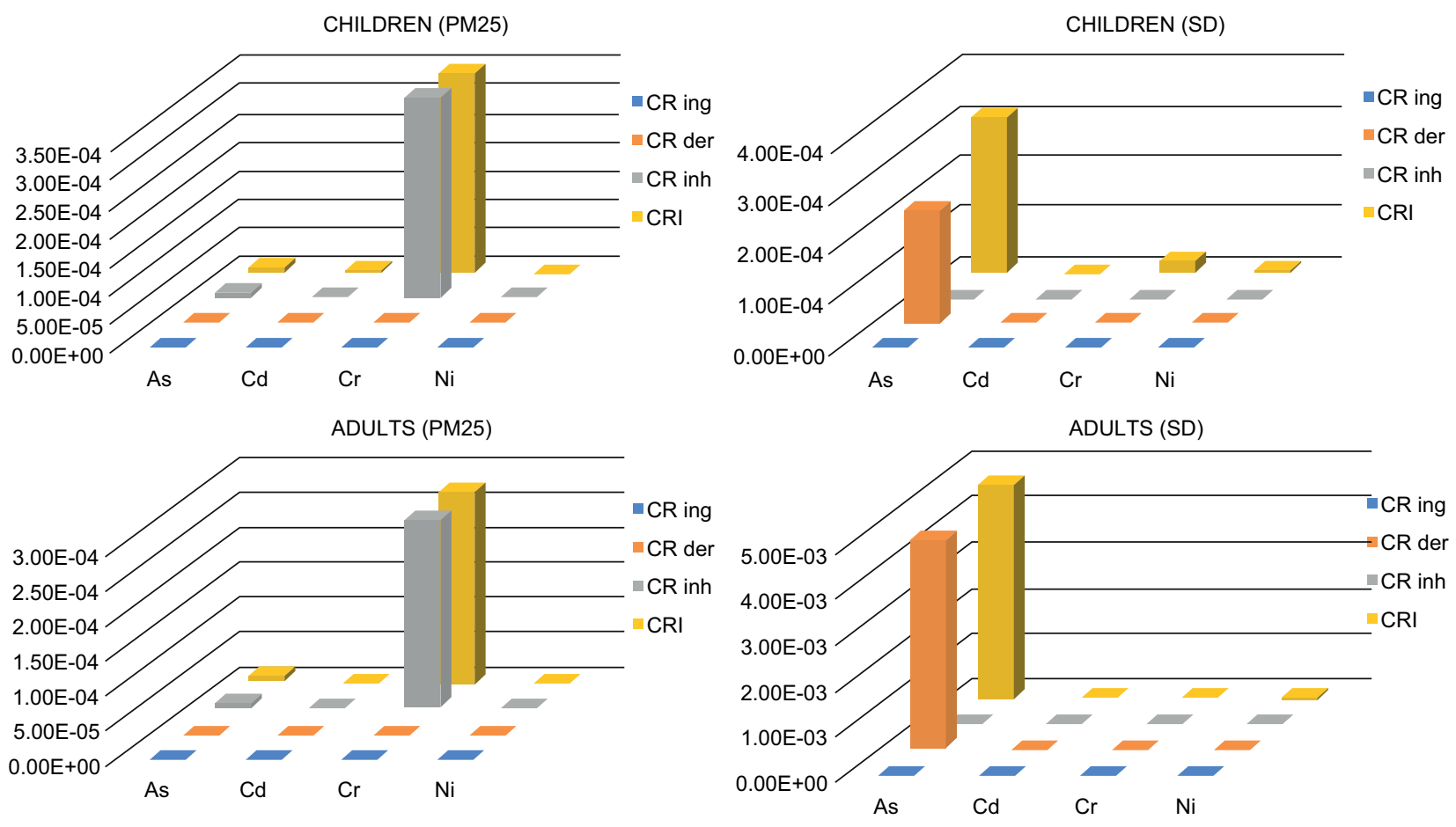

Fig. 3. Carcinogenic risk (CR) and carcinogenic risk index (CRI) in children and adults due to exposure to metal(loid)s through $\mathrm{PM}_{2.5}$ and sedimented dust (SD). 
$\mathrm{Cd}>\mathrm{Ni}$. Cr was 3.5 times over the upper limit of acceptability $\left(1 \times 10^{-4}\right)$, and As and Cd were 9.9 and 3.2 times over the lower limit of acceptability $\left(1 \times 10^{-6}\right)$, respectively, which is mainly explained by inhalation (99.4\%). For exposure through SD the order was $\mathrm{As}>\mathrm{Cr}>\mathrm{Ni}>\mathrm{Cd}$, where As was 3.0 times above the upper limit of acceptability $\left(1 \times 10^{-4}\right)$, and $\mathrm{Cr}$ and $\mathrm{Ni}$ were 30.1 and 7.0 times above the lower limit of acceptability $\left(1 \times 10^{-6}\right)$, respectively. The dermal and digestive routes represent the highest percentage of CR (74.9 and 25.1 $\%$, respectively). The integrated CRI $\left(\mathrm{PM}_{2.5}+\mathrm{SD}\right)$ calculation found that $\mathrm{As}, \mathrm{Cr}, \mathrm{Cd}$ and $\mathrm{Ni}$ are the metal(loid)s with the highest risk, whose main route is inhalation, followed by the digestive and dermal pathways. In adults the CRI through $\mathrm{PM}_{2.5}$ was $\mathrm{Cr}$ $>\mathrm{As}>\mathrm{Cd}>\mathrm{Ni}$, with $\mathrm{Cr}$ being 2.7 times over the upper acceptable limit $\left(10^{-4}\right)$. The risk for As and Cd was between the limits of acceptability: 9.2 and 2.5 times over the lower acceptable limit $\left(10^{-6}\right)$, which is due almost exclusively to inhalation. For $\mathrm{SD}$, As was 4.5 times above the upper limit of $1 \times$ $10^{-4}$, while $\mathrm{Ni}>\mathrm{Cr}>\mathrm{Cd}>$ were $74.3,14.6$ and 3.2 times above the lower acceptable limit $\left(10^{-6}\right)$, respectively, being the dermic route the most relevant (99.9\%). Integrating the risks of $\mathrm{PM}_{2.5}$ and $\mathrm{SD}$, As and $\mathrm{Cr}$ were above the upper limit $\left(10^{-4}\right)$, and $\mathrm{Ni}$ and $\mathrm{Cd}$ above the lower limit $\left(10^{-6}\right)$, respectively, with exposure through SD being the most relevant, especially dermal exposure.

One of the strengths of this study is that we integrated the information of two highly contaminated environmental matrices in the city of Chañaral, particles and sedimented dust, which are two very relevant source of exposure to population living in the study area (Yohannessen et al. 2015). Metals and metalloids were determined in school and residential microenvironments (indoor and outdoor) during two times of the year (winter and summer), and the information was integrated to give a better idea of the average exposure throughout the year with different meteorological conditions (Martínez et al. 2016, Mesías et al. 2018). On the other hand, the determinations of metals(loid)s were carried out in centers with a recognized experience in the determination of environmental compounds. All possible routes of exposure (inhalation, digestive and dermal contact) were considered in two relevant age groups (adults and children).

One of the weaknesses of any risk assessment is that it assumes that individuals will be exposed in the same place, at a fixed environmental concentration and that there is a $100 \%$ absorption (bioavailability) of contaminants by the body. However, it is expected that exposures will be different as exposed individuals leave a highly contaminated area. In this case, the contamination is limited to the entire city and therefore the exposure in school and residential environments is rather homogeneous. On the other hand, the differences in activity patterns from the individuals and exposure to sensibility vary, for this reason these studies consider different age strata and different microenvironments. Also, from a risk estimation point of view, we can only assume additive effects and the presence of synergy or antagonism between various contaminants cannot be evaluated.

Contaminant intake through food was not considered, since to date there are no specific published studies of the patterns of food consumption by the northern population of Chile, nor of their metal and metalloid content. However, the national food consumption survey reports that the consumption of fish and shellfish is more frequent in the northern macrozone compared to the central and southern parts of the country (ENCA 2014). It has been widely studied that marine products for human consumption extracted from coastal areas contaminated by industrial activities (such as mining) can bioaccumulate metals in their tissues, which can pass to humans through food (Usero et al. 2005, VicenteMartorell et al. 2009). A recent study carried out on mollusks extracted in the Chañaral Bay reported high contents of $\mathrm{Cd}, \mathrm{Cu}$ and $\mathrm{Zn}$ in their muscle mass compared to those extracted from coastal areas not impacted by mine tailings (Fuenzalida 2017). On the other hand, Raimann et al. (2014) studied the mercury $(\mathrm{Hg})$ content in 18 fish species of high consumption in Chile, reporting levels above the $1.5 \mathrm{mg} / \mathrm{kg}$ norm for Albacore, which is abundant in the study region. Another important source that may be associated with the high contamination of rivers in Chile, which impacts agriculture and the food chain that is reaching the consumer, are mining activities, natural orogenic processes, volcanic activity, and geology. Pizarro et al. (2010) suggest that the main source of contamination of the rivers of central-northern Chile could be mining activities, especially regarding elements such as $\mathrm{Cu}$, As and $\mathrm{Hg}$, listing some rivers as the most polluted in the world. Taking these studies into consideration, it is expected to consider that exposure to metals and metalloids through the consumption of possibly contaminated food is also a relevant route of entry into the body in the population studied, which is why it should be evaluated in future studies. 


\section{CONCLUSION}

The most abundant elements in SD and $\mathrm{PM}_{2.5}$ were closely related to the elements found in mining wastes such as tailings. This reaffirms the thesis that the elements determined in the studied environments have an anthropogenic origin and that they would be closely related to the deposits of mine tailings present in Chañaral Bay.

Children exposed to $\mathrm{As}, \mathrm{Cr}$ and $\mathrm{Cu}$ through $\mathrm{SD}$ via the digestive tract have a high potential risk of suffering a non-carcinogenic adverse effect (HQ > 1) compared to adults, whose HQ was lower than the unit. In the case of $\mathrm{PM}_{2.5}$ only $\mathrm{Cr}$ was significant for children. In terms of cancer risk, higher risks were determined by exposure to metal(loid) $\mathrm{s}$ through the inhalation of $\mathrm{PM}_{2.5}$, and through the dermal and digestive pathways for SD, especially in children and to a lesser extent in adults. It is necessary to continue investigating the effect of these metal(loid)s in the population, integrating other routes of exposure and factors associated with their bioavailability and possible interactions of multimetal contaminated soil

\section{ACKNOWLEDGMENTS}

This study was supported by the Project of National Funding to Health Research of Chile (FONIS) $\mathrm{N}^{\circ}$ SA11- I-2224, "Evaluación de los efectos agudos por exposición continua al material particulado proveniente de relaves mineros sobre la salud respiratoria de escolares en la ciudad de Chañaral, Región de Atacama, Chile". Paulina Flores Jiménez and Kelly Hernández appreciate the support of the International Exchange Program for Minority Students led by Dr. Luz Claudio at the Icahn School of Medicine at Mount Sinai in New York City. The authors also want to thank the authorities of Chañaral and its inhabitants, who allowed us to carry out this investigation.

\section{REFERENCES}

Anderson E.L. and Albert R.E. (2019). Risk assessment and indoor air quality. Indoor air research series. Center for Indoor Air Research (CIAR). CRC Press, Taylor \& Francis, Boca Raton, FL, EUA, 272 pp.

Asante-Duah K. (2017). Public health risk assessment for human exposure to chemicals. Environmental pollution, 2nd. ed. Springer, Dordrecht, Netherlands, 600 pp. https:doi.org/10.1007/978-94-024-1039-6
ASTM (2003). Standard practice for collection of floor dust for chemical analysis. Annual book of American Society for Testing Materials standards, West Conshohocken, PA, USA. https://doi.org/10.1520/D5438-17

Astudillo F. (2008). Análisis y propuesta de acción de la problemática ambiental en la Bahía de Chañaral. Departamento de Metalurgia, Facultad de Ingeniería, Universidad de Atacama, Copiapó, Chile.

Barbieri E., Fonturbel F.E., Herbas C., Barbieri F.L. and Gardon J. (2014). Indoor metallic pollution and children exposure in a mining city. Sci. Total Environ. 487, 13-19. https://doi.org/10.1016/j.scitotenv.2014.03.136

Barceloux D.G. (1999). Chromium. Clinical Toxicology 37 (2), 173-194. https://doi.org/10.1081/Clt-100102418

BCN, 2015. Reportes Comunales. Chañaral. Reportes Estadísticos. Biblioteca del Congreso Nacional de Chile [online]. https://www.bcn.cl/siit/reportescomunales/ comunas_v.html?anno $=2015 \&$ idcom $=3201$ 23/5/2020

Bernard A. (2008). Cadmium \& its adverse effects on human health. Indian J. Med. Res. 128 (4), 557-564.

Briki M., Zhu Y., Gao Y., Shao M., Ding H. and Ji H. (2017). Distribution and health risk assessment to heavy metals near smelting and mining areas of Hezhang, China. Environ. Monit. Assess. 189 (9), 458. https://doi.org/10.1007/s10661-017-6153-6

Carkovic A.B., Calcagni M.S., Vega A.S., Coquery M., Moya P.M., Bonilla C.A. and Pasten P.A. (2016). Active and legacy mining in an arid urban environment: Challenges and perspectives for Copiapó, northern Chile. Environ. Geochem. Health 38 (4), 1001-1014. https://doi.org/10.1007/s10653-016-9793-5

Cartieaux E., Rzepka M.A. and Cuny D. (2011). Qualité de l'air à l'intérieur des écoles. Arch. Pediatr. 18 (7), 789-796. https://doi.org/10.1016/j.arcped.2011.04.020

Castellucci I., Viviani C. and Martínez M. (2015). Confección de base de datos antropométricos de la población trabajadora chilena, especificando las diferencias de género. Universidad de Valparaíso, Chile. Mutual de Seguridad, Cámara Chilena de Comercio, 36 pp.

Castilla J. (1983). Environmental impacts in sandy beaches of copper mine tailing at Chañaral, Chile. Marine Pollution Bulletin 14 (12), 459-464. https:// doi.org/10.1016/0025-326X(83)90046-2

Chen Q.Y., DesMarais T. and Costa M. (2019). Metals and mechanisms of carcinogenesis. Annu. Rev. Pharmacol. Toxicol. 59, 537-554. https://doi.org/10.1146/annurevpharmtox-010818-021031

Csavina J., Field J., Taylor M.P., Gao S., Landazuri A., Betterton E.A. and Saez A.E. (2012). A review on the importance of metals and metalloids in atmospheric dust and aerosol from mining operations. Sci. Total Environ. 433, 58-73. https://doi.org/10.1016/j.scitotenv.2012.06.013 
Das K.K., Das S.N. and Dhundasi S.A. (2008). Nickel, its adverse health effects \& oxidative. Indian J. Med. Res. 128 (4), 412-425.

Diociaiuti M., Balduzzi M., De Berardis B., Cattani G., Stacchini G., Ziemacki G., Marconi A. and Paoletti L. (2001). The two PM(2.5) (fine) and PM(2.5-10) (coarse) fractions: Evidence of different biological activity. Environ. Res. 86 (3), 254-262. https://doi. org/10.1006/enrs.2001.4275

Dold B. (2006). Element flows associated with marine shore mine tailings deposits. Environ. Sci. Technol. 40, 752-758. https://doi.org/10.1021/es051475z

ENCA (2014). Encuesta nacional de consumo alimentario (ENCA): Informe final. Ministerio de Salud de Chile [online]. https://www.minsal.cl/enca/ 4/07/2020

Fonturbel F.E., Barbieri E., Herbas C., Barbieri F.L. and Gardon J. (2011). Indoor metallic pollution related to mining activity in the Bolivian Altiplano. Environ. Pollut. 159 (10), 2870-2875. https://doi.org/10.1016/j. envpol.2011.04.039

Fuenzalida F. (2017). Niveles de $\mathrm{Cd}, \mathrm{Cu}$ y $\mathrm{Zn}$ en la lapa Fissurella sp. en el borde costero de la comuna de Chañaral. B.Sc. thesis. Facultad de Ciencias, Universidad de Chile, Santiago, Chile, 66 pp. [online]. http:// repositorio.uchile.cl/handle/2250/146536 3/7/2020

Gidhagen L., Kahelin H., Schmidt-Thomé P. and Johansson C. (2002). Anthropogenic and natural levels of arsenic in PM10 in central and northern Chile. Atmos. Environ. 36, 3803-3817. https://doi.org/10.1016/ S1352-2310(02)00284-4

Goix S., Point D., Oliva P., Polve M., Duprey J.L., Mazurek H., Guislain L., Huayta C., Barbieri F.L. and Gardon J. (2011). Influence of source distribution and geochemical composition of aerosols on children exposure in the large polymetallic mining region of the Bolivian Altiplano. Sci. Total Environ. 412-413, 170184. https://doi.org/10.1016/j.scitotenv.2011.09.065

Gray D.L., Wallace L.A., Brinkman M.C., Buehler S.S. and La Londe C. (2015). Respiratory and cardiovascular effects of metals in ambient particulate matter: A critical review. Rev. Environ. Contam. Toxicol. 234, 135-203. https://doi.org/10.1007/978-3-31910638-0_3

Jorquera H. and Barraza F. (2013). Source apportionment of $\mathrm{PM}(10)$ and $\mathrm{PM}(2.5)$ in a desert region in northern Chile. Sci. Total Environ. 444, 327-335. https://doi. org/10.1016/j.scitotenv.2012.12.007

Kim H.S., Kim Y.J. and Seo Y.R. (2015). An overview of carcinogenic heavy metal: molecular toxicity mechanism and prevention. J. Cancer Prev. 20 (4), 232-240. https:// doi.org/10.15430/JCP.2015.20.4.232

Lee M. and Correa J. (2005). Effects of copper mine tailings disposal on littoral meiofaunal assemblages in the Atacama region of northern Chile. Mar. Environ. Res. 59 (1), 1-18. https://doi.org/10.1016/j.marenvres.2004.01.002

Li Z., Ma Z., van der Kuijp T.J., Yuan Z. and Huang L. (2014). A review of soil heavy metal pollution from mines in China: pollution and health risk assessment. Sci. Total Environ. 468-469, 843-853. https://doi. org/10.1016/j.scitotenv.2013.08.090

Martínez L., Mesías S., Yohannessen K., Alvarado S., Klarián J., Martín M., Costilla R., Fuentes M., Maldonado A., Torres R. and Cáceres D.D. (2016). Indooroutdoor concentrations of fine particulate matter in school building microenvironments near a mine tailing deposit. AIMS Environmental Science 3 (4), 752-764. https://doi.org/10.3934/environsci.2016.4.752

Masto R.E., George J., Rout T.K. and Ram L.C. (2017). Multi element exposure risk from soil and dust in a coal industrial area. J. Geochem. Explor. 176, 100-107. https://doi.org/10.1016/j.gexplo.2015.12.009

Mayan O.N., Gomes M.J., Henriques A., Silva S. and Begonha A. (2006). Health survey among people living near an abandoned mine. A case study: Jales mine, Portugal. Environ. Monit. Assess. 123 (1-3), 31-40. https://doi.org/10.1007/s10661-005-9078-4

Medina M., Andrade S., Faugeron S., Lagos N., Mella D. and Correa J. (2005). Biodiversity of rocky intertidal benthic communities associated with copper mine tailing discharges in northern Chile. Mar. Pollut. Bull. 50 (4), 396-409. https://doi.org/10.1016/j.marpolbul.2004.11.022

Mesías S., Martínez L., Yohannessen K., Alvarado S., Klarian J., Martín M., Costilla R., Fuentes M. and Cáceres D.D. (2018). Trace element contents in fine particulate matter $\left(\mathrm{PM}_{2.5}\right)$ in urban school microenvironments near a contaminated beach with mine tailings, Chañaral, Chile. Environ. Geochem. Health 40 (3), 1077-1091. https://doi.org/10.1007/s10653-017-9980-z

MINSAL (2018). Patrones de crecimiento para la evaluación nutricional de niños, niñas y adolescentes desde el nacimiento hasta los 19 años de edad. Ministerio de Salud de Chile, Subsecretaría de Salud Pública. http:// www.bibliotecaminsal.cl/patrones-de-crecimientopara-la-evaluacion-nutricional-de-ninos-ninas-yadolescentes-desde-el-nacimiento-hasta-los-19-anosde-edad/23/5/2020

Montenegro G., Fredes C., Mejías E., Bonomelli C. and Olivares L. (2009). Contenido de metales pesados en suelos cercanos a un relave cuprífero chileno. Agrociencia 43 (4), 427-435.

Morais S., Garcia e Costa F. and Pereira M. (2012). Heavy metals and human health. Environmental health Emerging issues and practice. IntechOpen, London, UK. https://doi.org/ 10.5772/29869 
Moreno M.E., Acosta-Saavedra L.C., Meza-Figueroa D., Vera E., Cebrián M.E., Ostrosky-Wegman P. and Calderón-Aranda E.S. (2010). Biomonitoring of metal in children living in a mine tailings zone in southern Mexico: A pilot study. Int. J. Hyg. Environ. Health 213 (4), 252-258. https://doi.org/10.1016/j.ijheh.2010.03.005

O’Neal S.L. and Zheng W. (2015). Manganese toxicity upon overexposure: A decade in review. Curr. Environ. Health Rep. 2 (3), 315-328. https://doi.org/10.1007/ s40572-015-0056-X

Oeder S., Jorres R.A., Weichenmeier I., Pusch G., Schober W., Pfab F., Behrendt H., Schierl R., Kronseder A., Nowak D., Dietrich S., Fernandez-Caldas E., Lintelmann J., Zimmermann R., Lang R., Mages J., Fromme H. and Buters J.T. (2012). Airborne indoor particles from schools are more toxic than outdoor particles. Am. J. Respir. Cell. Mol. Biol. 47 (5), 575-582. https:// doi.org/10.1165/rcmb.2012-0139OC

Pizarro J., Vergara P.M., Rodríguez J.A. and Valenzuela A.M. (2010). Heavy metals in northern Chilean rivers: Spatial variation and temporal trends. J. Hazard. Mater. 181 (1-3), 747-754. https://doi.org/10.1016/j. jhazmat.2010.05.076

Raimann X., Rodríguez O.L., Chávez P. and Torrejón C. (2014). Mercurio en pescados y su importancia en la salud. Rev. Med. Chil. 142 (9), 1174-1180. https://doi. org/10.4067/S0034-98872014000900012

Ramírez M., Massolo S., Frache R. and Correa J.A. (2005). Metal speciation and environmental impact on sandy beaches due to El Salvador copper mine, Chile. Mar. Pollut. Bull. 50 (1), 62-72. https://doi.org/10.1016/j. marpolbul.2004.08.010

Ratnaike R.N. (2003). Acute and chronic arsenic toxicity. Postgrad. Med. J. 79 (933), 391-396. https://doi. org/10.1136/pmj.79.933.391

Roohani N., Hurrell R., Kelishadi R. and Schulin R. (2013). Zinc and its importance for human health: An integrative review. J. Res. Med. Sci. 18 (2), 144-157.

Schwartz J and Neas L. (2000). Fine particles are more strongly associated than coarse particles with acute respiratory health effects in school children. Epidemiol. 11, 6-10. https://doi.org/10.1097/00001648200001000-00004

Stern B.R. (2010). Essentiality and toxicity in copper health risk assessment: overview, update and regulatory considerations. J. Toxicol. Environ. Health A 73 (2-3), 114-127. https://doi.org/10.1080/15287390903337100

Tapia J.S., Valdes J., Orrego R., Tchernitchin A., Dorador C., Bolados A. and Harrod C. (2018). Geologic and anthropogenic sources of contamination in settled dust of a historic mining port city in northern Chile: Health risk implications. PeerJ. 6, e4699. https://doi. org/10.7717/peerj.4699
USEPA (1989). EPA/540/1-89/002. Risk assessment guidance for superfund. Vol. I. Human health evaluation manual (Part A). United States Environmental Protection Agency, Washington DC, USA, 291 pp.

USEPA (1999). EPA/625/R-96/010a. Determination of metals in ambient particulate matter using X-Ray fluorescence (XRF) spectroscopy. Compendium methods IO-3.3. Cincinnati, OH 45268, United States Environmental Protection Agency, Washington DC, USA, $36 \mathrm{pp}$.

USEPA (2009). EPA-540-R-070-002. Risk assessment guidance for superfund. Vol. I. Human health evaluation manual (Part F, supplemental guidance for inhalation risk assessment). United States Environmental Protection Agency, Washington DC, USA, 68 pp.

USEPA (2015) EPA/600/R-07/041. ProUCL Version 5.1 User guide statistical software for environmental applications for data sets with and without non-detect observations. United States Environmental Protection Agency, Office of Research and Development. Washington DC, USA, $272 \mathrm{pp}$.

Usero J., Morillo J. and Gracia I. (2005). Heavy metal concentrations in molluscs from the Atlantic coast of southern Spain. Chemosphere 59 (8), 1175-1181. https://doi.org/10.1016/j.chemosphere.2004.11.089

Vergara A. (2011). Cuando el río suena, piedras trae: Relaves de cobre en la bahía de Chañaral, 19381990. Cuadernos de Historia 35, 135-151. https://doi. org/10.4067/S0719-12432011000200005

Vicente-Martorell J.J., Galindo-Riano M.D., GarcíaVargas M. and Granado-Castro M.D. (2009). Bioavailability of heavy metals monitoring water, sediments and fish species from a polluted estuary. J. Hazard Mater. 162 (2-3), 823-836. https://doi.org/10.1016/j. jhazmat.2008.05.106

Voulvoulis N., Skolout J.W.F., Oates C.J. and Plant J.A. (2013). From chemical risk assessment to environmental resources management: the challenge for mining. Environ. Sci. Pollut. R. 20 (11), 7815-7826. https:// doi.org/10.1007/s11356-013-1785-8

Wani A.L., Ara A. and Usmani J.A. (2015). Lead toxicity: A review. Interdiscip. Toxicol. 8 (2), 55-64. https://doi. org/10.1515/intox-2015-0009

Williamson B.J., Udachin V., Purvis O.W., Spiro B., Cressey G. and Jones G.C. (2004). Characterisation of airborne particulate pollution in the $\mathrm{Cu}$ smelter and former mining town of Karabash, South Ural Mountains of Russia. Environ. Monit. Assess. 98 (1-3), 235-259. https://doi.org/10.1023/ b:emas.0000038189.45002.78,

Wisskirchen C. and Dold B. (2006). The marine shore porphyry copper mine tailings deposit at Chañaral, northern Chile. 7th International Conference on Acid Rock 
Drainage. St. Louis Missouri, March 27-30, 2480-2489 [online]. https://doi.org/10.21000/JASMR06022480

Yohannessen K., Alvarado S., Mesías S., Klarián J., Silva C., Vidal D. and Cáceres D. (2015). Exposure to fine particles by mine tailing and lung function effects in a panel of schoolchildren, Chañaral, Chile. J. Environ. Prot. 6, 118-128. https://doi.org/10.4236/jep.2015.62014 Zhang X.Y., Tang L.S., Zhang G. and Wu H.D. (2009). Heavy metal contamination in a typical mining town of a minority and mountain area, South China. Bull. Environ. Contam. Toxicol. 82 (1), 31-38. https://doi. org/10.1007/s00128-008-9569-4
Zheng J., Huynh T., Gasparon M., Ng J. and Noller B. (2013). Human health risk assessment of lead from mining activities at semi-arid locations in the context of total lead exposure. Environ. Sci. Pollut. Res. Int. 20 (12), 8404-8416. https://doi.org/10.1007/s11356013-2145-4

Zheng N., Liu J., Wang Q. and Liang Z. (2010). Health risk assessment of heavy metal exposure to street dust in the zinc smelting district, northeast of China. Sci. Total Environ. 408 (4), 726-733. https://doi.org/10.1016/j. scitotenv.2009.10.075 


\section{SUPPLEMENTARY MATERIAL}

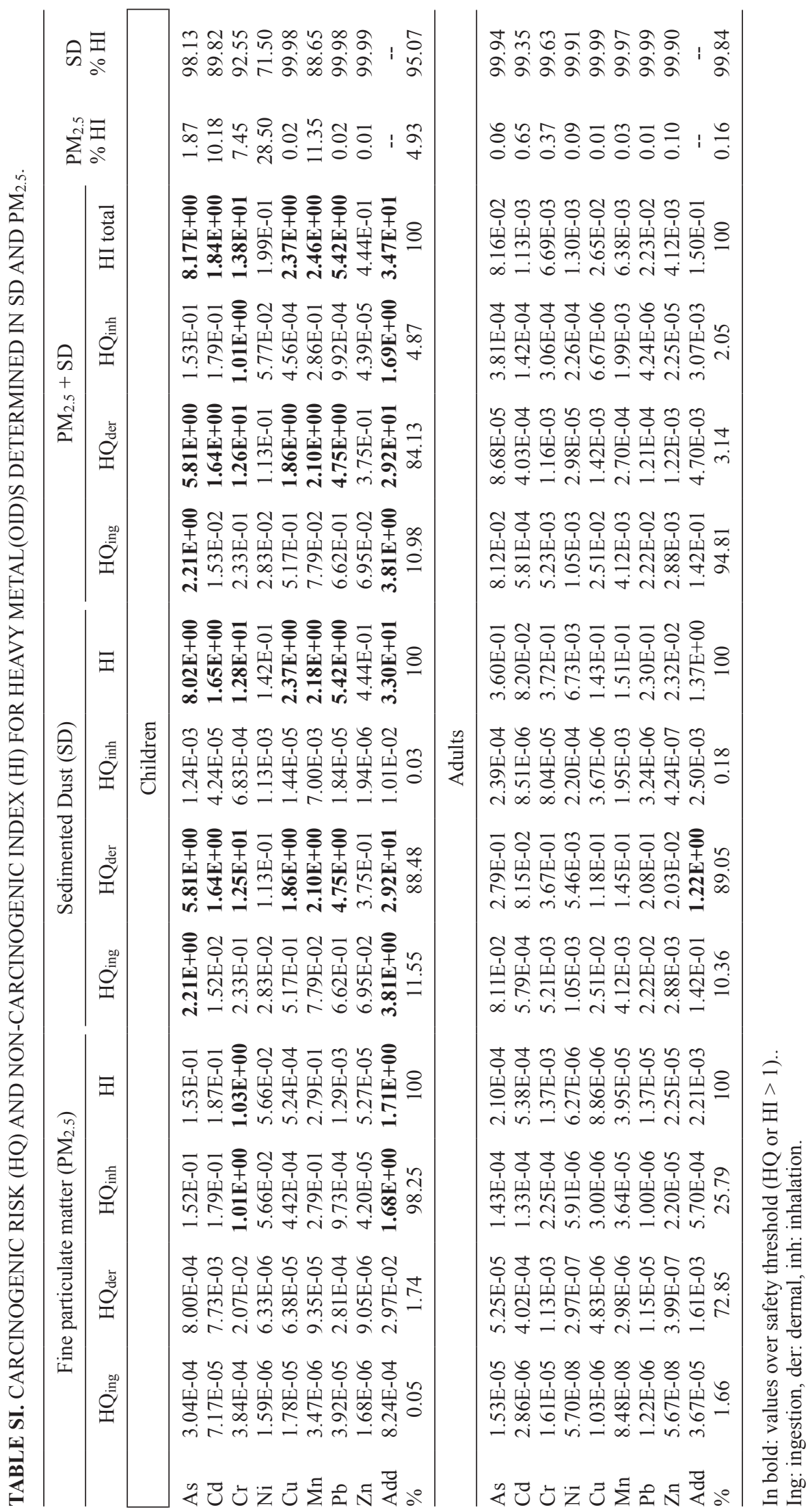




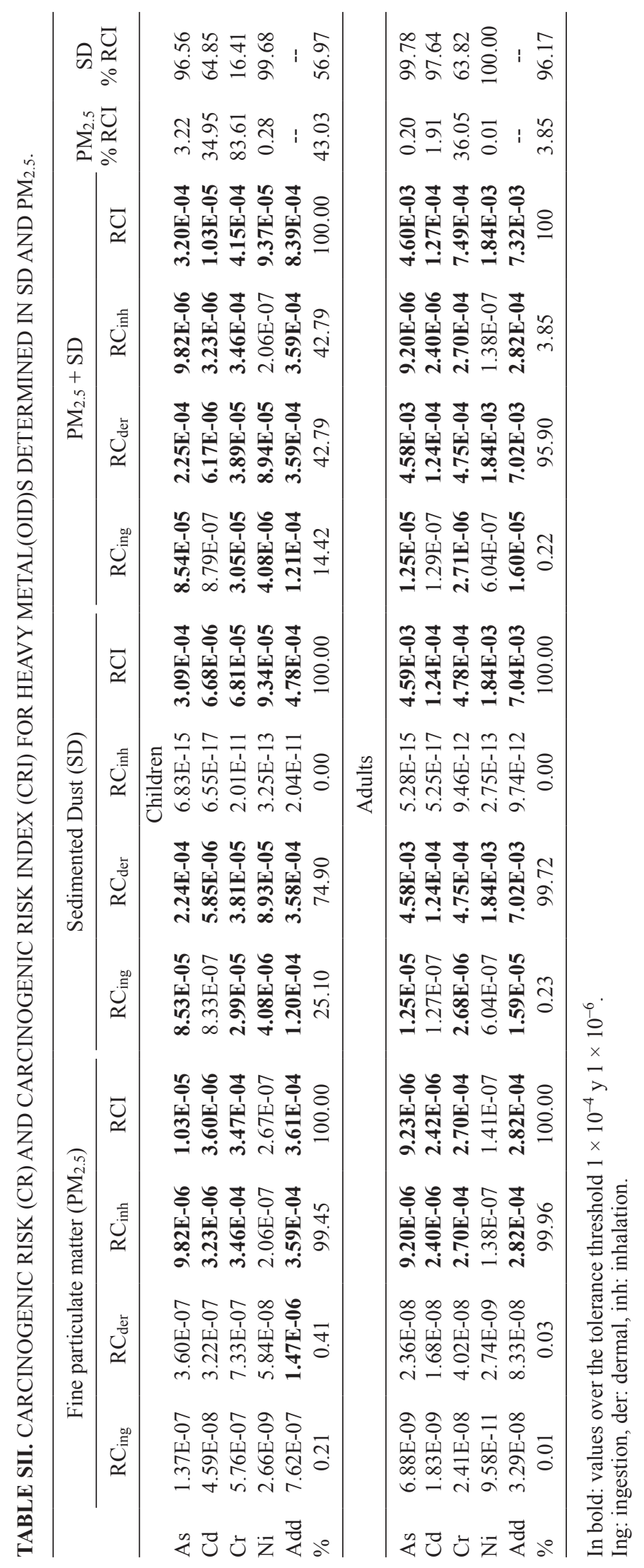

